\title{
Influence of stretching exercises in musculoskeletal pain in nursing professionals
}

\author{
Influência de exercícios de alongamento na dor \\ musculoesquelética em Profissionais de Enfermagem
}

\section{Influencia de ejercicios de estiramiento en el dolor musculoesquelético en profesionales de la enfermería}

\author{
José Nunes da Silva Filho ${ }^{[[a]}$, Jonas Lírio Gurgel $\mathbb{[}^{[b]}$, Flávia Porto $\mathbb{C}^{[c] *}$ \\ [a] Secretaria de Educação da Prefeitura Municipal de Paraguaçu Paulista, São Paulo, SP, Brazil \\ [b] Universidade Federal Fluminense (UFF), Rio de Janeiro, RJ, Brazil \\ [c] Universidade do Estado do Rio de Janeiro (UERJ), Rio de Janeiro, RJ, Brazil
}

\section{Abstract}

Introduction: Nursing professionals (NPs) experience musculoskeletal pain that leads them to leave work. Objective: To analyze the effects of muscle stretching exercises (MSE) on pain among NPs. Method: This is a randomized controlled parallel experiment, in which 28 NPs (7 men and 21 women) were allocated into experimental (EG, $\mathrm{n}=15 ; 47.4$ years \pm 9.5 ) and control (CG, $\mathrm{n}=13 ; 39.15$ years \pm 9.6 ) groups. MSEs were performed for two months, three days a week, 40 min per session. A visual numeric scale was used, for which the intensity ranged from 0 (no pain) to 10 (maximum pain). The research was registered at the Brazilian Clinical Trials Registry website (TRIAL: RBR- 8chg6q). For statistics, the Shapiro-Wilk, T-independent and two-way ANOVA tests were applied for repeated measures with Tukey's post-hoc test $(\mathrm{P} \leq 0.05)$. Results: Most NPs work on weekends (68\%) and/or have other professional activities (60.7\%); 42.9\% had to miss work at least once in the year prior to the survey and $66.7 \%$ of those were due to medical reasons; $42.9 \%$ work more than 10 hours/day. Of the NPs, 89.3\% of the volunteers in both groups lived daily with pain in some region of the body. Pain decreased after the MSE program was initiated in the EG $(p=0.001)$ and differed from the CG $(p=0.002)$. Conclusion: MSEs were beneficial for pain reduction in NPs.

Keywords: Exercise. Nursing Staff. Pain.

\footnotetext{
* JNSF: MS, e-mail: jose_nunes_99@hotmail.com JLG: PhD, e-mail: jonasgurgel@terra.com.br FP: PhD, e-mail: flaviaporto30@gmail.com
} 


\section{Resumo}

Introdução: um número elevado de Profissionais de Enfermagem (PEF) sentem dor em alguma região do corpo, principalmente na região lombar, o que muitas vezes acaba afastando-os de suas atividades laborais. Objetivo: analisar os efeitos de exercícios de alongamento muscular (EAM) na dor em Profissionais de Enfermagem (PEF). Método: realizou-se um experimento clínico, controlado e randomizado, de desenho paralelo, com uma amostra de 28 PEF (7 homens e 21 mulheres), com idades entre 18 e 60 anos, divididos, aleatoriamente, em grupo experimental (GE: $n=15$ ) e grupo controle (GC: $n=13$ ). Os EAM foram oferecidos por dois meses, em três dias semanais. As sessões de EAM tiveram duração de 40 min compostas por exercícios ativos e estáticos de alongamento. Cada exercício foi repetido por 4 séries de 30s, com intervalo de 30s entre elas. Para a medição de dor nos PEF, foi usada uma escala visual numérica, na qual a intensidade variava entre 0 (ausência de dor) a 10 (máxima intensidade de dor). Essa medição era feita antes, logo após e ao término do programa de oito semanas de EAM. A presente pesquisa foi registrada no portal de Registro Brasileiro de Ensaios Clínicos (TRIAL: RBR-8chg6q). Resultados: para interação grupo $x$ dor, notou-se que houve diferença significativa $(F=6,5 ; p=0,002) e$, que, somente, para o GE, as dores aguda e crônica foram, significativamente, menores que a dor inicial ( $p=0,001)$. Conclusão: o alongamento produziu efeitos agudo e crônico positivos na redução da dor em PEF.

Palavras-chave: Exercício. Equipe de Enfermagem. Algia.

\section{Resumen}

Introducción: un alto número de profesionales de enfermería (PEF) sienten dolor en alguna región del cuerpo, especialmente en la región lumbar, que a menudo termina alejándolos de sus actividades laborales. Objetivo: analizar los efectos de los ejercicios de estiramiento muscular (EEM) en el dolor en los Profesionales de Enfermería (PEF). Método: se llevó a cabo un experimento clínico, controlado y aleatorio, de diseño paralelo, con una muestra de 28 PEF (7 hombres y 21 mujeres), con edad entre 18 y 60 años, divididos aleatoriamente en un grupo experimental (GE: $n=15$ ) y un grupo de control (GC: $n=13)$. Los EEM se ofrecieron durante dos meses, en tres días de la semana. Las sesiones de EEM duraron 40 minutos compuestos de ejercicios de estiramientos activos y estáticos. Cada ejercicio se repitió por 4 series de 30s, con un intervalo de 30s entre ellos. Para la medición del dolor en los PEF, se utilizó una escala visual numérica, en la que la intensidad osciló entre 0 (ausencia de dolor) y 10 (intensidad máxima del dolor). Esta medición se realizó antes, poco después y al final del Programa de ocho semanas de los EEM. Esta investigación se registró en el portal de Registro Brasileño de Ensayos Clínicos (TRIAL: RBR-8chg6q). Resultados: para la interacción del grupo x del dolor, se observó que había una diferencia significativa ( $F=6,5 ; p=0,002)$ y que solo para el GE, el dolor agudo y crónico era significativamente menor que el dolor inicial ( $p=0,001)$. Conclusión: el estiramiento produjo efectos agudos y crónicos positivos en la reducción del dolor de los PEF.

Palabras clave: Ejercicio. Equipo de Enfermería. Dolor.

\section{Introduction}

In Brazil, the term "Nursing Professionals" (NPs) is understood as the group formed by nursing assistants, licensed practical nurses, and registered nurses, who differ in their technical qualification and their tasks assigned in a health unit [1]. The working environment makes these professionals a risk group for the development of occupational diseases [2]. Prolonged maintenance of repetitive postures and movements $[3,4]$, accumulation of working hours, and handling improperly maintained 
equipment (beds, stretchers, wheelchairs, etc.) are risk factors for the development of work-related diseases in NPs [5].

Nonspecific pain is multifactorial and affects several professional classes, however, Davis and Kotowski [6] indicate, through reviews, a higher prevalence of pain in NPs, especially in the lower back, regardless of personal and work characteristics.

Because NPs perform their tasks with pain, other damage, such as psychological disorders, emotional exhaustion, and suffering may affect their health [7]. Moreover, long and repetitive work schedules become a harmful and sacrificing activity for these professionals [5]. Furthermore, pain has been considered as one of the main causes of absenteeism among them [8].

To alleviate pain, exercise is considered an effective alternative $[9,10]$, especially to lighten back pain $[9,11]$. Different exercise strategies have been researched for this purpose, such as Pilates, manual therapy, weight training, stretching, and Yoga, among others, in different populations of workers such as industrialists, day laborers, workpeople, and NPs [12,13].

Regarding muscle stretching exercises (MSE), positive effects on posture [13,14], blood pressure [15], increased range of motion [16], or as a complement for gym classes have been reported in literature [17]. However, for pain alleviation, such studies have no consensus [10].

The aim of this study was to determine the effects of MSE on pain in NPs. Such effects have been hypothesized to be positive, since MSE can reduce the level of activation and muscle fatigue $[18,19]$, thus suggesting an acute effect. The chronic effect could be explained by the fact that MSE reduces muscle imbalance [20] and musculoskeletal pain, which interferes with daily living habits [21].

\section{Method}

This was a randomized, controlled, parallel experiment that followed Resolution 466 of the National Health Council of December 12, 2012. It was approved by the Research Ethics Committee of the Medical School of the Fluminense Federal University, through the opinion with protocol number: 679.764/2014 and CAAE: 31287514.3.0000.5243. This research was also registered on the Brazilian Clinical Trials Registry website (TRIAL: RBR- 8chg6q).
The sample consisted of 28 NPs, aged 18 to 60 years, from a population of 32 employees of a polyclinic in the city of Niterói-RJ, who experienced pain in some part of their body and were not practicing any guided physical activity in the period of participation in the research. Self-reportedly, the participants stated that they were not taking any medication or undergoing physical therapy. The volunteers were selected by convenience after formal invitation and individual explanation of all research procedures -, then randomly allocated to two groups: the experimental group $(E G=15)$, aged $47.4 \pm 9.5$ years, and the control group $(C G=13)$, aged $39.14 \pm 9.6$ years. The randomization process took place via software (Microsoft Excel 2010), as a way to produce low risk of bias, according to the guidelines by De Carvalho, Silva, and Grande [22].

\section{Procedures}

Before the beginning of classes, the work profile, anthropometric characteristics, and level of musculoskeletal pain of the volunteers were investigated. Immediately following the first session and at the end of eight weeks, the volunteers had their pain reevaluated. The evaluators were not blind to the group to which the volunteer belonged. Figure 1 shows the research design.

Regarding the CG, the individuals underwent the same evaluations; however, they did not participate in MSE sessions. At the end of the study, individual research volunteers were provided with individual reports containing the results of all measurements taken.

To describe the NPs profile in this study, two questionnaires were applied: the 'Well-Being Pentacle' [23], which is a model that estimates the components of lifestyle and individual well-being; and the 'Professional Data Questionnaire' [24], which seeks to answer questions about workers' functional activities.

In the anthropometric assessment, height and body mass were measured to calculate the body mass index (BMI), which was performed according to the recommendations of the International Standards for Anthropometric Assessment [25]. To do so, we used a portable stadiometer (EST 22, Cachoeira do Sul, RS, Brazil) with a maximum capacity of $2 \mathrm{~m}$, a minimum of $0.3 \mathrm{~m}$ and an accuracy of $0.001 \mathrm{~m}$; 
mechanical scale (Filizola, mod. 31, Osasco, SP, Brazil) with an accuracy of $100 \mathrm{~g}$ and a maximum capacity of $150 \mathrm{~kg}$; and anthropometric tape (CESCORF Ltda., Porto Alegre, RS, Brazil), according to Silva Filho et al. [13]. For BMI, we adopted the World Health Organization (WHO) classification for adults of both sexes, which classifies the individual from 'low weight' (BMI $\leq 18.5 \mathrm{~kg} / \mathrm{m}^{2}$ ) to 'grade 3 obesity' $\left(\mathrm{BMI} \geq 40 \mathrm{~kg} / \mathrm{m}^{2}\right.$ ) and relates the risk of comorbidities [26].

To measure pain, we used a questionnaire consisting of closed questions regarding the presence or absence of pain, pain intensity and location, movements that aggravate pain, and a drawing in which the subjects could indicate where they were feeling pain [27].

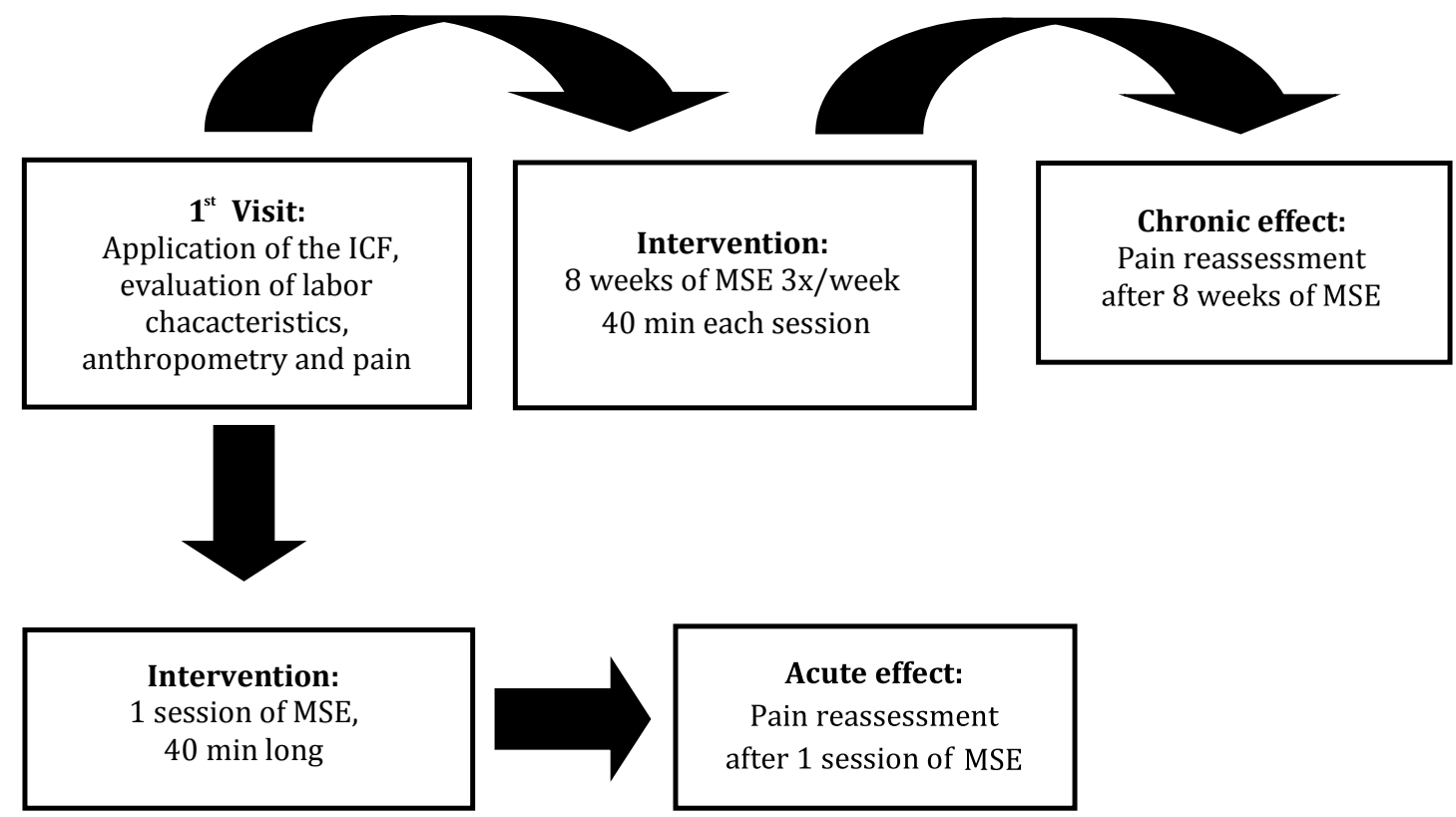

Note: ICF: Informed Consent Form.

Figure 1-Research steps.

\section{Muscle stretching exercises (MSE)}

The MSE program was conducted for 8 weeks. Each session lasted 40 minutes, consisting of active static stretching exercises with the guidance and supervision of a Physical Education teacher. Classes were offered three days a week, with a 48-hour rest between sessions, as recommended by the American College of Sports Medicine [28]. Each volunteer was to attend at least two of the sessions. The frequency of attendance of the volunteers was recorded and monitored daily by the teacher.

All sessions consisted of static and active stretching exercises for the upper limbs, trunk, hips, and lower limbs. Each exercise comprised of four sets of $30 \mathrm{~s}$, with intervals of $30 \mathrm{~s}$ between sets.

For intensity control, the volunteers were instructed to slowly move the muscle group up to a slight discomfort to prevent possible strain. They were to remain in that position for the stipulated time. During all sessions, relaxation music was played.

\section{Statistical treatment}

Statistical calculations were performed using software (SPSS ${ }^{\mathrm{TM}} 21$, Chicago, IL, USA), adopting a significance level of $p \leq 0.05$. Initially, the ShapiroWilk test was used to evaluate the normality of the samples. For comparisons between the characteristics of the groups, an independent T-test was applied and, to check the group versus pain interaction, the two-way ANOVA test for repeated measures was used with the post-hoc test.

\section{Results}

Figure 2 shows the flowchart of the volunteers who were evaluated by the eligibility criteria adopted for this study. 
The anthropometric characteristics of the sample are described in Table 1, in which the groups showed a significant difference only in age $(\mathrm{p}=0.03)$.

Regarding the work profile of the NPs in both groups, Figure 3A shows a large percentage of NPs working on weekends and/or other professional activities. In addition, it states that approximately half of them had to be absent for health reasons without specifying the medical reasons for such. Figure 3B shows results regarding the time and type of service of the NPs.

As for pain, it was observed that $89.3 \%(n=25)$ of the volunteers of both groups lived daily with pain in some region of the body at the beginning of the study, with the lower back being the place of highest pain incidence $(68 \%, n=19)$, followed by shoulder blades $(32 \%, \mathrm{n}=9)$ and shoulders $(21 \%, \mathrm{n}=6)$.

The $2 \times 3$ ANOVA $F$ result with repeated measures for group versus pain interaction is shown in Figure 4, with a statistically significant difference $(F=6.5$; $\mathrm{p}=0.002$ ), verified by Tukey's post hoc - Honestly Significant difference (HSD) for unequal samples. The groups were homogeneous regarding the initial pain symptom and, only in the EG, the acute and chronic pain were significantly lower than the initial pain $(\mathrm{p}=0.001)$.

As for pain, it was observed that $89.3 \%(n=25)$ of the volunteers of both groups lived daily with pain in some region of the body at the beginning of the study, with the lower back being the place of highest pain incidence $(68 \%, \mathrm{n}=19)$, followed by shoulder blades $(32 \%, \mathrm{n}=9)$ and shoulders $(21 \%, \mathrm{n}=6)$.

The $2 \times 3$ ANOVA F result with repeated measures for group versus pain interaction is shown in Graph 1 , with a statistically significant difference $(F=6.5$; $p=0.002$ ), verified by Tukey's post hoc - Honestly Significant difference (HSD) for unequal samples. The groups were homogeneous regarding the initial pain symptom and, only in the EG, the acute and chronic pain were significantly lower than the initial pain $(p=0.001)$.

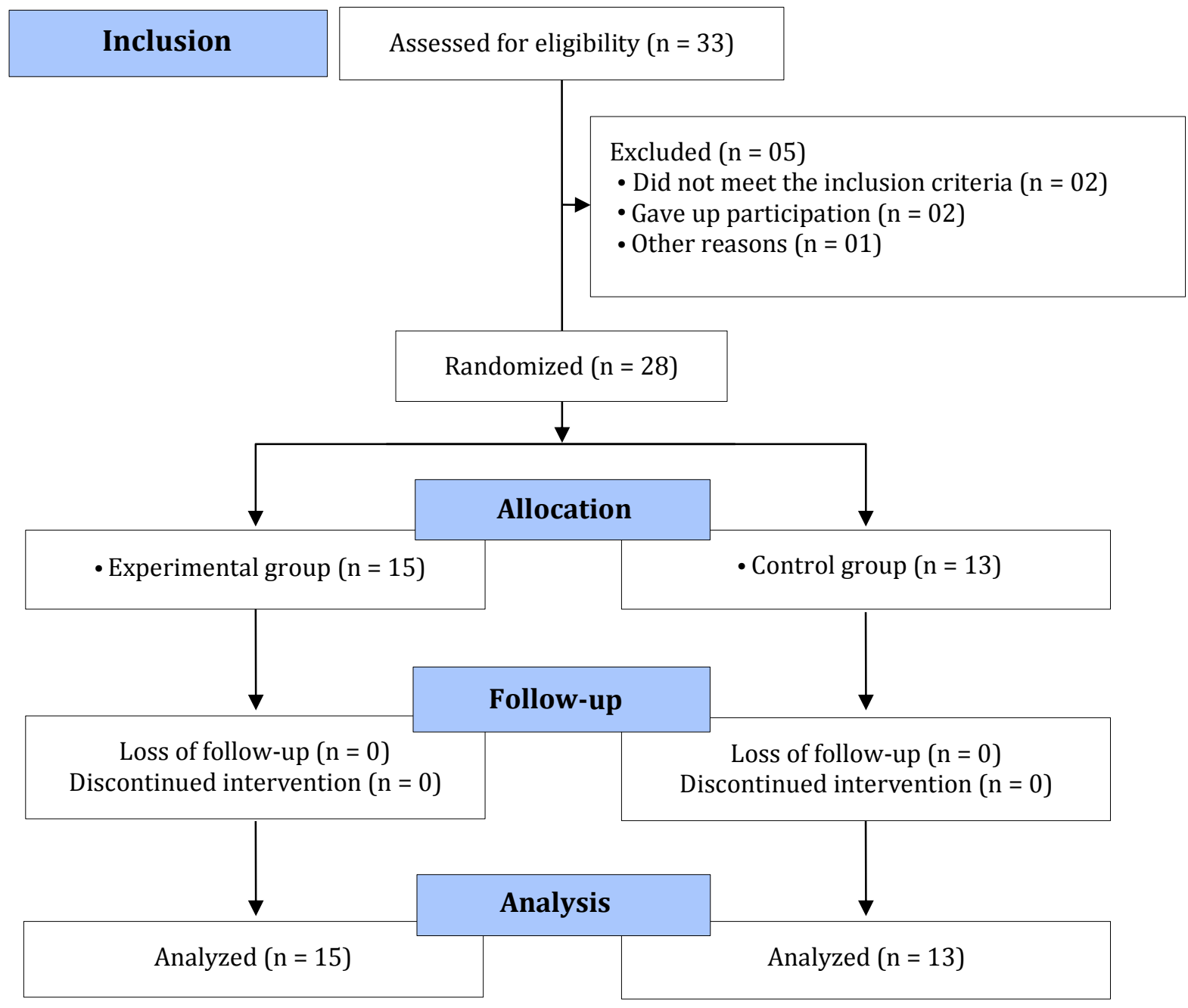

Figure 2 - Flowchart for selecting volunteers. 
Table 1 - Characteristics of the sample and comparison between groups

\begin{tabular}{|c|c|c|c|c|c|c|}
\hline \multirow{2}{*}{ Variables } & \multicolumn{2}{|c|}{$E G(n=15)$} & \multicolumn{2}{|c|}{$C G(n=13)$} & \multirow[t]{2}{*}{$p$} & \multirow[t]{2}{*}{$E S$} \\
\hline & $\mu-S D$ & $95 \% \mathrm{CI}$ & $\mu-S D$ & $95 \% \mathrm{Cl}$ & & \\
\hline Age (years) & $47.4 \pm 9.5$ & $42.1-52.6$ & $39.15 \pm 9.6$ & $33.3-44.9$ & $0.03^{*}$ & 0.860 \\
\hline BM (kg) & $68.6 \pm 14.4$ & $60.6-76.6$ & $72.5 \pm 10.5$ & $66-78.8$ & 0.43 & 0.301 \\
\hline Height (m) & $1.60 \pm 0.07$ & $1.56-1.64$ & $1.64 \pm 0.07$ & $1.60-1.69$ & 0.14 & 0.570 \\
\hline$\% \mathrm{BF}$ & $26.1 \pm 7.8$ & $24.7-30.5$ & $24.9 \pm 7.4$ & $20.4-29.4$ & 0.68 & 0.158 \\
\hline BMI & $26.5 \pm 5$ & $23.7-29.3$ & $26.6 \pm 2.9$ & $24.8-28.3$ & 0.97 & 0.013 \\
\hline WHR & $0.83 \pm 0.08$ & $0.78-0.87$ & $0.80 \pm 0.07$ & $0.76-0.85$ & 0.42 & 0.308 \\
\hline
\end{tabular}

Note: CG: Control group; EG: Experimental group; BM: Body mass; BMI: Body Mass Index; Cl: Confidence interval; WHR: Waist-to-hip ratio; n: number of volunteers; $\mu$ : Mean; SD: Standard deviation; $p$ : statistical value; $\left(^{*}\right): p<0,05$; ES: Effect size.

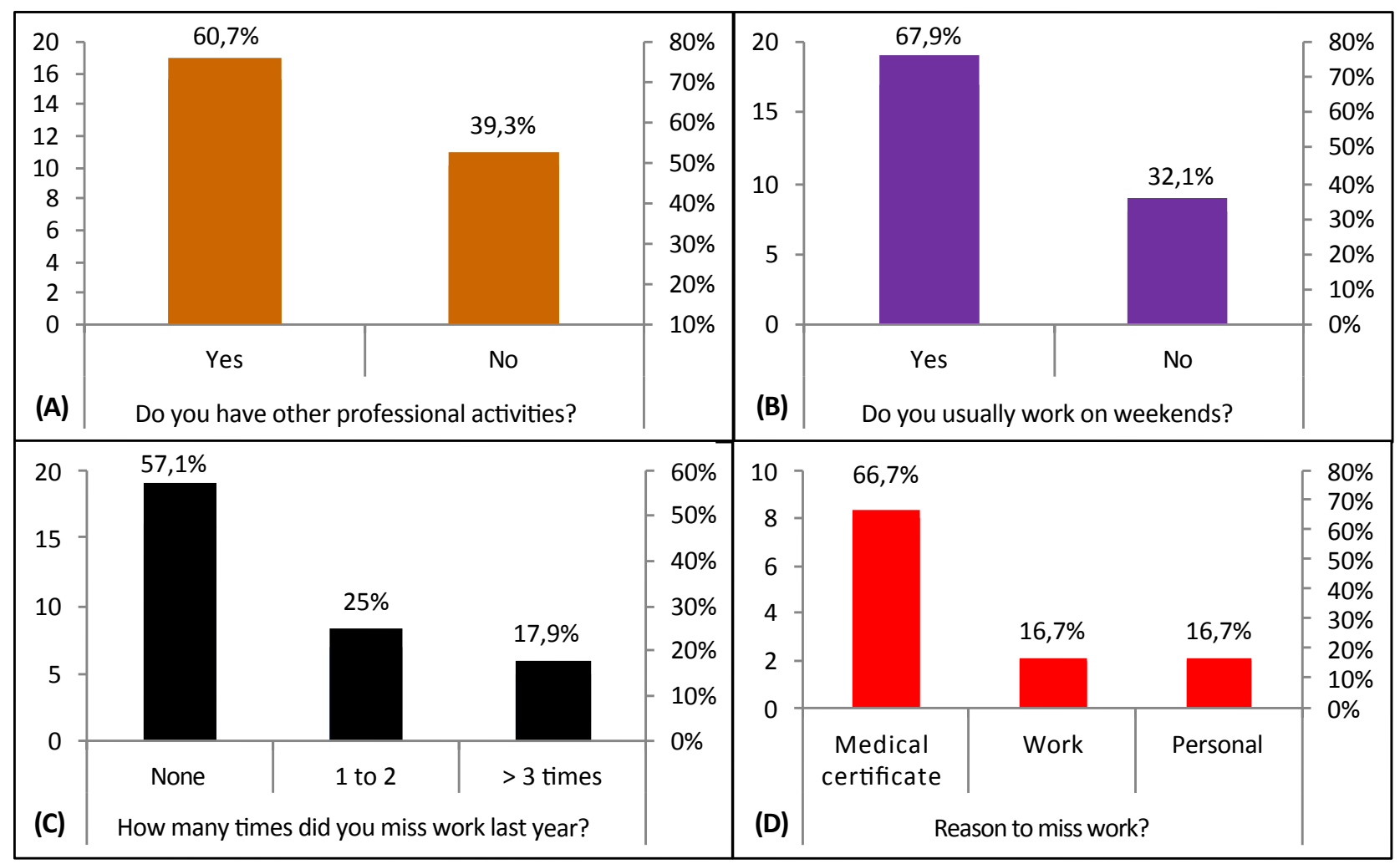

Figure $3 \mathrm{~A}-$ Workload and absence from work. 


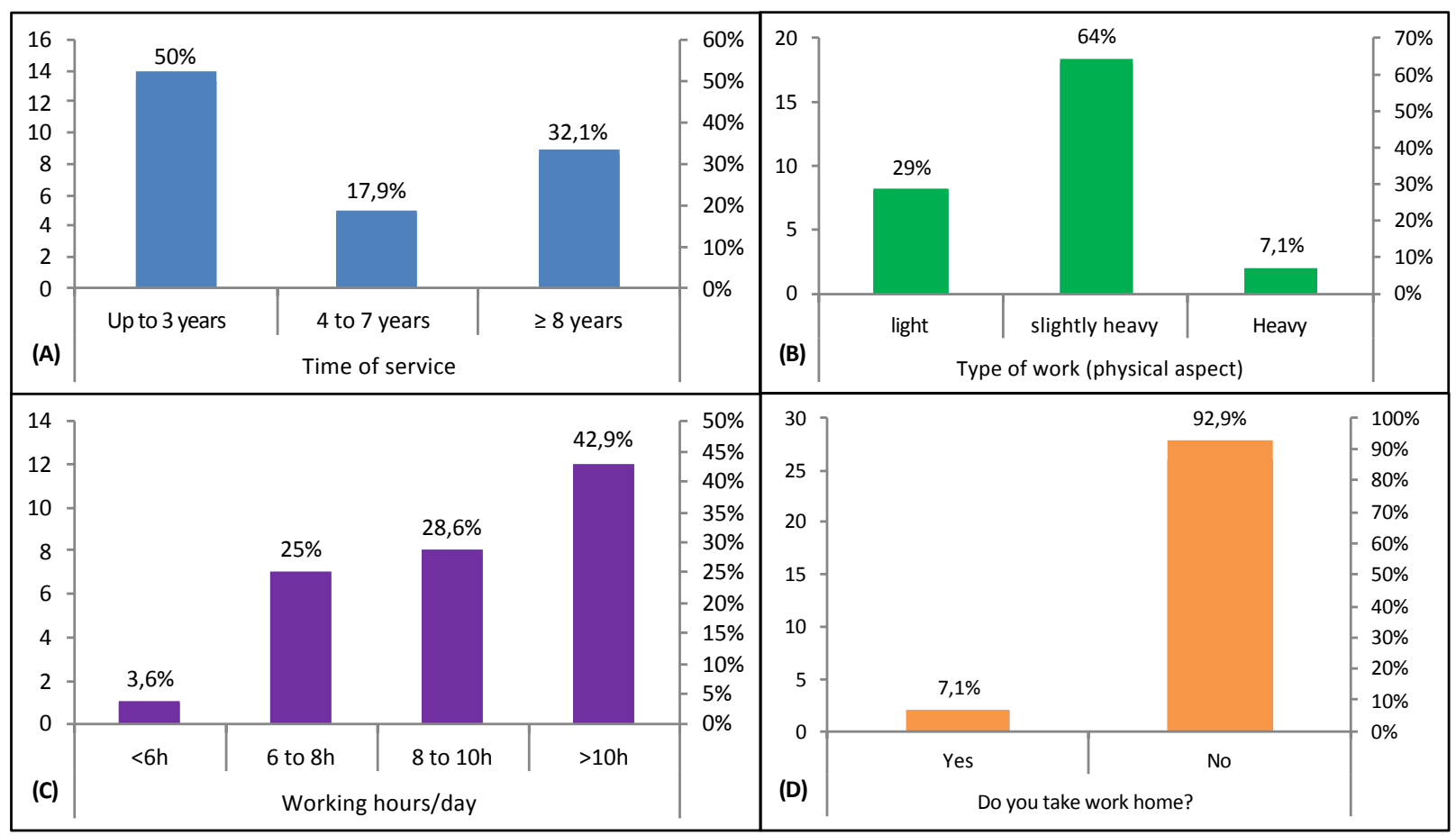

Figure 3B - Data regarding time and type of service.

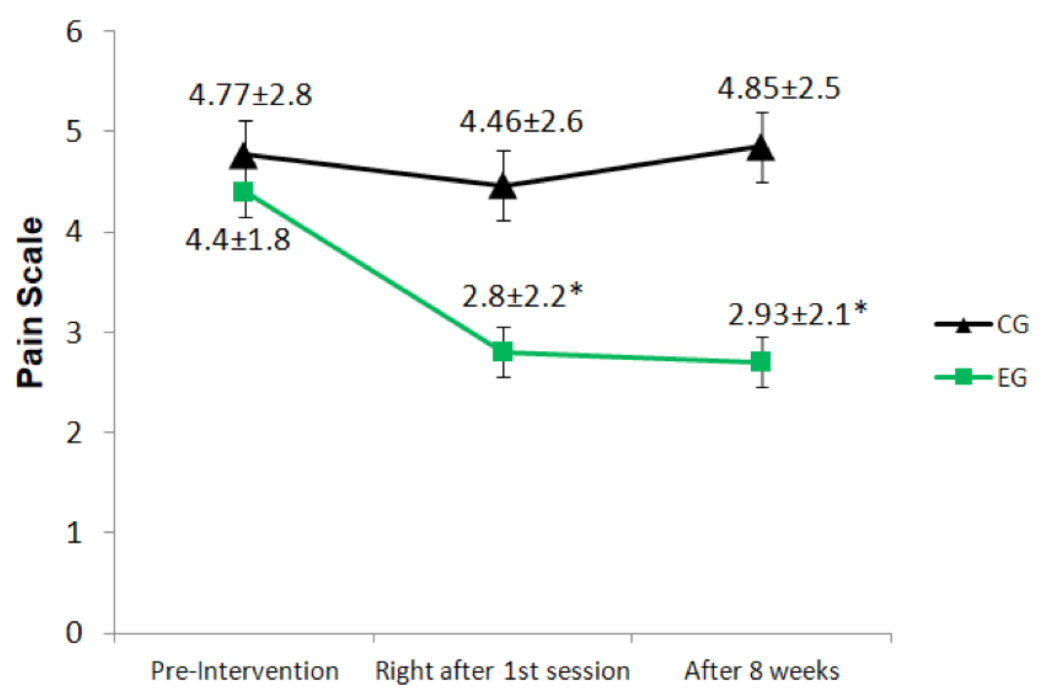

Note: CG: Control group; EG: Experimental group; $p$ : statistical value; *: $p<0.05$.

Figure 4-Effect of the MSE program on musculoskeletal pain in NPs.

\section{Discussion}

This study aimed to check the acute and chronic effects of MSE on pain in NPs. The main findings were that nearly $90 \%$ of the subjects lived daily with musculoskeletal pain, especially in the lower back. This corroborates other studies that also found a high incidence of pain in NPs [3, 29]. Magnago et al. [29] studied a group of 491 NPs and found that the most prevalent site of pain was in the lower back region, present in $71.5 \%$ of volunteers. One explanation can be attributed to the anatomy of the lumbar vertebrae that makes the region conducive to the incidence of spinal injuries [30]. In other words, due to their morphological characteristics, besides protecting the spinal cord, the lumbar vertebrae can withstand high mechanical loads and have great mobility while maintaining stability for 
trunk and hip movement. Tension, compression, and shear or torsional forces are constantly supported by the lower back region, which makes them a risk zone for injuries. Therefore, they have a differentiated anatomy compared to other spinal vertebrae [31].

The mechanisms of musculoskeletal injury are related to the types of forces involved in performing movements or maintaining postures [32]. In the spine, flexion movements generate compression in the tissues, while extension movements cause traction in the region. In addition, the shear in intervertebral discs added to the posterior fissure and weakness of the fibrous ring leads to initial disc injury and posterior protrusion of the nucleus pulposus [30]. Considering the existence and role of intervertebral discs in spinal kinesiology, such forces combined and/or applied repeatedly, with or without the presence of overloads, may trigger intervertebral disc injuries, causing pain $[30,32]$.

The etiology of musculoskeletal pain seems unknown [33], but physical exercise is considered an effective non-pharmacological strategy for pain relief $[9,10]$. In this study, it was noted that both the acute effect of one exercise session and the chronic effect after 8 weeks generated a significant reduction in pain level. In the EG, initially, $93.3 \%$ of volunteers felt back pain and, after the intervention, acutely and chronically, this percentage decreased to $73.3 \%$ and $80 \%$, respectively. That is, there was a $20 \%$ reduction in people who felt pain in the EG and $13 \%$ in the CG. In its acute effect, MSE may reduce the level of muscle activation and fatigue, and in its chronic effect, MSE may attenuate muscular imbalance, factors which are closely linked to the sensation of pain [19-21].

The beneficial effect of exercise on the sensation of pain observed in the NPs, in this study, confirms the findings of literature. An Asian survey by Chen et al. [34] verified the effectiveness of an MSE program on lower back pain in $127 \mathrm{NPs}$, separated into EG and CG, followed for 24 weeks; in the study, the EG showed significantly lower pain scores than the CG after the intervention. This type of intervention has also been investigated in other individual profiles and the results have also been positive, similar to the study by Puppin et al. [33], in which the effect of 8 weeks of MSE in 55 patients with back pain was evaluated, and the outcomes showed a significant reduction in pain in the EG compared to the CG. In another study, conducted with 31 women allocated to either the EG and CG, after 6 weeks of MSE, patients with back pain had decreased pain sensations at the end of the study when compared to the CG [11].

MSE proved to be efficient and might be a means of intervention in individuals with pain, which positively interferes with their daily living and work activities $[21,29]$. On the other hand, the possible placebo effect that the intervention may have had on volunteers should be considered. In this regard, Lindheimer, O'Connor, and Dishman [35] pointed out that the placebo effect accounts for about $50 \%$ of the psychological benefits seen as a consequence of physical training. However, both for a better understanding of the placebo effect related to exercise and the mechanisms involved in occupational pain, further studies are needed.

This study showed relevant information on the role of physical exercise in the occupational health of nursing professionals, a group that is at risk for the development of occupational diseases, but which, however, has a large representativeness in the workforce in the health area. Although the sample size was small, the findings corroborate what literature already indicates regarding the benefits that physical exercise may generate in the individual's health. Even if the placebo effect is considered, regular physical activity constitutes a healthy lifestyle and should also be promoted to health professionals as a way to take care for themselves as they take care of others.

\section{Conclusion}

This study concluded that for this NP sample, MSE promoted positive changes, reducing the level of musculoskeletal pain soon after one session and after 8 weeks of training.

\section{Acknowledgements}

To the Brazilian National Council for Scientific and Technological Development (CNPq) for funding this study (Master's scholarship). 


\section{References}

1. Peduzzi M, Anselmi ML. O auxiliar e o técnico de enfermagem: categorias profissionais diferentes e trabalhos equivalentes. Rev Bras Enferm. 2004;57(4);425-9.

2. MacPhee M, Dahinten V, Havaei F. The impact of heavy perceived nurse workloads on patient and nurse outcomes. Adm Sci. 2017;7(1):1-17.

3. Castro AB. Handle with care: The American Nurses Association's campaign to address work-related musculoskeletal disorders. Online J Issues Nurs. $2004 ; 9(3): 3$.

4. Anap DB, Iyer C, Rao K. Work related musculoskeletal disorders among hospital nurses in rural Maharashtra, India: a multi centre survey. Int J Res Med Sci. 2017;1(2):101-7.

5. Batiz E, Vergara L, Licea O. Análise comparativa entre métodos de carregamento de cargas e análise postural de auxiliares de enfermagem. Prod. 2012;22(2):270-83.

6. Davis KG, Kotowski SE. Prevalence of musculoskeletal disorders for nurses in hospitals, long-term care facilities, and home health care: a comprehensive review. Hum Factors. 2015;57(5):754-92.

7. Freimann T, Coggon D, Merisalu E, Animägi L, Pääsuke M. Risk factors for musculoskeletal pain amongst nurses in Estonia: a cross-sectional study. BMC Musculoskelet Disord. 2013;14:334.

8. Shamian J, Kerr MS, Laschinger HK, Thomson D. A hospital-level analysis of the work environment and workforce health indicators for registered nurses in Ontario's acute-care hospitals. Can J Nurs Res Arch. 2002;33(4):35-50.

9. Searle A, Spink M, Ho A, Chuter V. Exercise interventions for the treatment of chronic low back pain: a systematic review and meta-analysis of randomised controlled trials. Clin Rehab. 2015;29(12):1155-67.
10. Schaafsma FG, Whelan $K$, van der Beek AJ, van der Es-Lambeek LC, Ojajärvi A, Verbeek JH. Physical conditioning as part of a return to work strategy to reduce sickness absence for workers with back pain. Cochrane Database Syst Rev. 2013;(8):CD001822.

11. Cunha ACV, Burke TN, França FJR, et al. Effect of global posture reeducation and of static stretching on pain, range of motion, and quality of life in women with chronic neck pain: a randomized clinical trial. Clinics. 2008;63(6):763-70.

12. Park JH, Lee SH, Ko DS. The effects of the Nintendo Wii exercise program on chronic work-related low back pain in industrial workers. J Phys Ther Sci. 2013;25(8):985-8.

13. Silva Filho JN, Gurgel JL, Silva EB, Porto F. Acute and chronic effect of stretching exercise on posture and flexibility of nurses and licensed practical nurses. Man Ther, Posturology Rehabil J. 2017;15(478):1-6.

14. Silva Filho JN, Gurgel JL, Porto F. Effects of stretching exercises for posture correction: systematic review. Man Ther, Posturology Rehabil J. 2014;12:265-72.

15. Wong A, Figueroa A. Eight weeks of stretching training reduces aortic wave reflection magnitude and blood pressure in obese postmenopausal women. J Hum Hypertens. 2014;28(4):246-50.

16. Dallas G, Smirniotou A, Tsiganos G, Tsopani D, Di Cagno A, Tsolakis Ch. Acute effect of different stretching methods on flexibility and jumping performance in competitive artistic gymnasts. J Sports Med Phys Fitness. 2014;54(6):683-90.

17. D’Anna C, Gómez-Paloma F. Dynamic stretching versus static stretching in gymnastic performance. J Hum Sport Exerc. 2015;10(1):S437-46.

18. Chiu TC, Ngo HC, Lau LW, Leung KW, Lo MH, Yu HF, Ying M. An Investigation of the Immediate Effect of Static Stretching on the Morphology and Stiffness of Achilles Tendon in Dominant and Non-Dominant Legs. PloS One. 2016;11(4):e0154443. 
19. Yahia A, Jribi S, Ghroubi S, Elleuch M, Baklouti S, Habib Elleuch M. Evaluation of the posture and muscular strength of the trunk and inferior members of patients with chronic lumbar pain. Joint Bone Spine. 2011;78(3):291-7.

20. Granito RN. Efeitos do envelhecimento e da osteoporose na cifose torácica, na propriocepção e no torque dos músculos do tronco [dissertação]. São Carlos: Universidade Federal de São Carlos; 2005.

21. Dolphens M, Cagnie B, Coorevits P, Vanderstraeten G, Cardon G, D’hooge R, Danneels L. Sagittal standing posture and its association with spinal pain: a school-based epidemiological study of 1196 Flemish adolescents before age at peak height velocity. Spine (Phila Pa 1976). 2012;37(19):1657-66.

22. Carvalho A, Silva V, Grande AJ. Avaliação do risco de viés de ensaios clínicos randomizados pela ferramenta da colaboração Cochrane. Diagn Tratamento. 2013;18(1): 38-44.

23. Nahas MV, Barros MVG, Francalacci V. O pentáculo do bem-estar: base conceitual para avaliação do estilo de vida de indivíduos ou grupos. Rev Bras Ativ Fis Saude. 2000;5(2):48-59.

24. Alvarez BR. Qualidade de vida relacionada à saúde de trabalhadores: um estudo de caso [dissertação]. Florianópolis: Universidade Federal de Santa Catarina; 1996.

25. Marfell-Jones MJ, Stewart AD, Ridder JH. International standards for anthropometric assessment. Potchefstroom: Isak; 2012.

26. Organização Mundial da Saúde. Glossário de promoção da saúde. Genebra: OMS; 1998.

27. Candotti C, Guimarães A. Emprego do método de relaxamento muscular de Leon Michaux no tratamento da dor lombar de atletas de ginástica rítmica desportiva. Perfil. 1998;2(2):19-27.

28. American College of Sports Medicine. ACSM's guidelines for exercise testing and prescription. Philadelphia: Lippincott Williams \& Wilkins; 2013.
29. Magnago TSBS, Lisboa MTL, Griep RH, Kirchhof ALC, Guido LA. Psychosocial aspects of work and musculoskeletal disorders in nursing workers. Rev Latino-Am Enfermagem. 2010;18(3):429-35.

30. Mcnitt-Gray JL. Carga no sistema musculoesquelético durante a aterrissagem. In: Zatsiorski VM, editor. Biomecânica no esporte: performance do desempenho e prevenção de lesão. Rio de Janeiro: Guanabara Koogan; 2004. p. 409-31.

31. Frost BA, Camarero-Espinosa S, Foster EJ. Materials for the Spine: Anatomy, Problems, and Solutions. Materials (Basel). 2019;12(2):E253.

32. Zernicke RF, Whitting WC. Mecanismos de lesão musculoesquelética. In: Zatsiorski VM, editor. Biomecânica no esporte: performance do desempenho e prevenção de lesão. Rio de Janeiro: Guanabara Koogan; 2004. p. 397-408.

33. Puppin MAFL, Marques AP, Silva AG, Futuro Neto HA. Alongamento muscular na dor lombar crônica inespecífica: uma estratégia do método GDS. Fisioter Pesqui. 2011;18(2):116-21.

34. Chen HM, Wang HH, Chen CH, Hu HM. Effectiveness of a stretching exercise program on low back pain and exercise self-efficacy among nurses in Taiwan: a randomized clinical trial. Pain Manag Nurs. 2014;15(1):283-91.

35. Lindheimer JB, O'Connor PJ, Dishman RK. Quantifying the placebo effect in psychological outcomes of exercise training: a meta-analysis of randomized trials. Sports Med. 2015;45(5):693-711.

Received on $04 / 23 / 2019$ Recebido em 23/04/2019 Recibido en 23/04/2019

Approved on 11/07/2019 Aprovado em 07/11/2019 Aprobado en 07/11/2019 